\title{
Hypoalbuminaemic hyponatraemia: a new syndrome?
}

\author{
P DANDONA, V FONSECA, D N BARON
}

\begin{abstract}
Six patients with severe hyponatraemia had neurological features of hyponatraemia and pronounced hypoalbuminaemia. All had biochemical features typical of the syndrome of inappropriate secretion of antidiuretic hormone with low serum osmolality and an inappropriately high urinary osmolality. All were given infusions of whole plasma or albumin solution, or both, to restore their plasma albumin concentrations to normal, which led to a dramatic increase in plasma sodium concentrations and serum osmolality, with a concomitant fall in urinary osmolality in all patients. Neurological features were reversed in four patients.

It is suggested that severe hypoalbuminaemia is an important cause of appreciable hyponatraemia; infusions of plasma and albumin in such patients may reverse the biochemical and clinical features and should form the basis of management.
\end{abstract}

\section{Introduction}

Biochemical hyponatraemia, defined as a plasma sodium concentration below $134 \mathrm{mmol}(\mathrm{mEq}) / 1$, is common. It does not usually cause clinical manifestations because various treatments reverse hyponatraemia while it is still at a preclinical stage. Impaired conscious-

Department of Chemical Pathology and Human Metabolism, Royal Free Hospital and School of Medicine, London NW3 2QG

P DANDONA, DPHIL, MRCP, senior lecturer in chemical pathology and director, metabolic unit

V FONSECA, MD, MRCP, research fellow

D N BARON, DSC, FRCP, professor

Correspondence to: Dr Dandona. ness and epileptiform seizures are usually associated only with severe hyponatraemia, below $120 \mathrm{mmol} / \mathrm{l}$. Various mechanisms may be responsible for the pathogenesis of hyponatraemia. ${ }^{1}$ Excessive loss of sodium and diminished clearance of water are probably the two most common causes of clinically important hyponatraemia. The first is commonly due to intestinal disease or diuretics, the second may be due to the syndrome of inappropriate secretion of antidiuretic hormone. ${ }^{34}$

Inappropriate secretion of antidiuretic hormone is well recognised in association with neoplasms secreting antidiuretic hormone and pulmonary disease. The occurrence of biochemical features characteristic of the syndrome, such as serum hypo-osmolality and urinary hyperosmolality, in association with hypovolaemia and hypoalbuminaemia has not been shown previously to be of clinical importance. We report on six patients in whom hyponatraemia and serum hypo-osmolality, with appreciable clinical abnormalities, were associated with features of urinary hyperosmolality and hypoalbuminaemia; correction of hypoalbuminaemia led to resolution of the biochemical abnormalities and clinical features of hyponatraemia. We also assessed the prevalence of the association of hyponatraemia and hypoalbuminaemia in hospital practice.

\section{Case reports}

We report below clinical and biochemical details of three patients. The table summarises the details of these and three other patients.

\section{CASE 1}

A 65 year old insulin dependent diabetic woman was admitted with diabetic ketoacidosis precipitated by a urinary infection. She was taking no drugs other than insulin. She was dehydrated, and her blood pressure was

Clinical features, plasma albumin and sodium concentrations, and plasma osmolality and urinary osmolality before and after infusions of albumin and plasma in patients with hypoalbuminaemia

\begin{tabular}{|c|c|c|c|c|c|c|}
\hline Case No & $\begin{array}{l}\text { Diagnosis and other } \\
\text { clinical features }\end{array}$ & Neurological features & $\underset{(\mathrm{g} / \mathrm{l})}{\operatorname{Albumin}}$ & $\begin{array}{l}\text { Sodium } \\
(\mathrm{mmol} / \mathrm{l})\end{array}$ & $\begin{array}{l}\text { Osmolality } \\
(\mathrm{mmol} / \mathrm{l})\end{array}$ & $\begin{array}{l}\text { Urinary osmolality } \\
(\mathrm{mmol} / \mathrm{l})\end{array}$ \\
\hline \multirow{2}{*}{1} & \multirow{2}{*}{ Diabetic ketoacidosis, volvulus of sigmoid colon } & $\left\{\begin{array}{l}\text { Before Confusion, drowsiness } \\
\text { After Features reversed }\end{array}\right.$ & 22 & $\begin{array}{l}114 \\
130\end{array}$ & $\begin{array}{l}240 \\
276\end{array}$ & $\begin{array}{l}575 \\
405\end{array}$ \\
\hline & & $\left.\begin{array}{l}\text { Before } \\
\text { After }\end{array}\right\}$ See text & $\begin{array}{l}20 \\
33\end{array}$ & $\begin{array}{l}118 \\
132\end{array}$ & $\begin{array}{l}245 \\
280\end{array}$ & $\begin{array}{l}495 \\
390\end{array}$ \\
\hline 2 & Carcinoma of colon totally resected. Postoperative malnutrition & $\left\{\begin{array}{l}\text { Before Confusion, drowsiness, epileptic fits } \\
\text { After Features reversed }\end{array}\right.$ & $\begin{array}{l}20 \\
33\end{array}$ & $\begin{array}{l}104 \\
128\end{array}$ & $\begin{array}{l}215 \\
275\end{array}$ & $\begin{array}{l}580 \\
350\end{array}$ \\
\hline 3 & $\begin{array}{l}\text { Congestive cardiac failure while taking diuretics. Dehydrated. } \\
\text { Hyponatraemia after rehydration }\end{array}$ & $\left\{\begin{array}{l}\text { Before Confusion } \\
\text { After Features reversed }\end{array}\right.$ & $\begin{array}{l}30 \\
34\end{array}$ & $\begin{array}{l}116 \\
128\end{array}$ & $\begin{array}{l}259 \\
276\end{array}$ & $\begin{array}{l}580 \\
430\end{array}$ \\
\hline 4 & Carcinoma of rectum totally resected. Postoperative malnutrition & $\left\{\begin{array}{l}\text { Before Confusion, drowsiness } \\
\text { After Features reversed }\end{array}\right.$ & $\begin{array}{l}25 \\
33\end{array}$ & $\begin{array}{l}118 \\
130\end{array}$ & $\begin{array}{l}245 \\
271\end{array}$ & $\begin{array}{l}520 \\
425\end{array}$ \\
\hline 5 & Acute myeloid leukaemia. No cause of loss of consciousness found & $\left\{\begin{array}{l}\text { Before Epileptic fit } \\
\text { After Prolonged loss of consciousness } \\
\text { (No change after further infusion) }\end{array}\right.$ & $\begin{array}{l}24 \\
32 \\
35\end{array}$ & $\begin{array}{l}119 \\
131 \\
135\end{array}$ & $\begin{array}{l}243 \\
270 \\
283\end{array}$ & $\begin{array}{l}625 \\
398 \\
\text { NA }\end{array}$ \\
\hline 6 & Hepatocellular carcinoma, ? Budd-Chiari syndrome & $\left\{\begin{array}{l}\text { Before Weakness, confusion } \\
\text { After Features reversed }\end{array}\right.$ & $\begin{array}{l}26 \\
34\end{array}$ & $\begin{array}{l}118 \\
130\end{array}$ & $\begin{array}{l}235 \\
278\end{array}$ & $\begin{array}{l}602 \\
425\end{array}$ \\
\hline
\end{tabular}

Conversion: SI to traditional units—Sodium: $1 \mathrm{mmol} / \mathrm{l}=1 \mathrm{mEq} / \mathrm{l}$. Plasma osmolality: $1 \mathrm{mmol} / \mathrm{l} \approx 1 \mathrm{mosmol} / \mathrm{l}$. Urinary osmolality: $1 \mathrm{mmol} / \mathrm{l} \approx 1 \mathrm{mosmol} / \mathrm{l}$. 
130/80 $\mathrm{mm} \mathrm{Hg}$. Her plasma electrolyte concentrations were sodium $138 \mathrm{mmol} / \mathrm{l}$, potassium $4 \cdot 2 \mathrm{mmol}(\mathrm{mEq}) / 1$, chloride $102 \mathrm{mmol}(\mathrm{mEq}) / \mathrm{l}$, bicarbonate $5 \mathrm{mmol}(\mathrm{mEq}) / 1$, and urea $10 \mathrm{mmol} / \mathrm{l}(60 \cdot 2 \mathrm{mg} / 100 \mathrm{ml})$. She was treated with physiological saline, potassium chloride, and insulin infusion intravenously. Ketoacidosis was corrected over eight hours, and 24 hours later she was being treated with subcutaneous insulin again and was eating regular meals. Two days later she developed oedema, which increased rapidly over the next 24 hours; her abdominal girth increased, ascites developed, and she began to vomit. An $x$ ray film of the abdomen showed distension of the large and small bowel and multiple fluid levels. She became confused and drowsy.

Her total plasma protein concentration fell from 63 to $39 \mathrm{~g} / \mathrm{l}$ and her albumin concentration from 38 to $22 \mathrm{~g} / 1$. Plasma sodium concentration fell from 138 to $114 \mathrm{mmol} / \mathrm{l}$, and plasma osmolality fell to $240 \mathrm{mmol}(\mathrm{mosmol}) / \mathrm{kg}$ while urinary osmolality rose to $575 \mathrm{mmol} / \mathrm{kg}$. Two litres of plasma were infused, and her total plasma protein and albumin concentrations increased to 58 and $33 \mathrm{~g} / \mathrm{l}$, respectively. Her oedema largely resolved over 18 hours, and the plasma sodium concentration increased to $130 \mathrm{mmol} / \mathrm{l}$.

Her level of consciousness improved. Two days later she became oedematous again with further ascites and abdominal distension. Plasma protein and albumin concentrations had fallen to 40 and $20 \mathrm{~g} / \mathrm{l}$, respectively, and she became confused and drowsy again. Plasma sodium concentration was $118 \mathrm{mmol} / \mathrm{l}$, plasma osmolality $245 \mathrm{mmol} / \mathrm{kg}$, and urinary osmolality $495 \mathrm{mmol} / \mathrm{kg}$. Concentrated albumin solution $(25 \% ; 200 \mathrm{ml})$ was infused, and her oedema diminished and plasma protein and albumin concentrations rose to 56 and $33 \mathrm{~g} / \mathrm{l}$, respectively; plasma sodium concentration and osmolality increased to $132 \mathrm{mmol} / \mathrm{l}$ and $280 \mathrm{mmol} / \mathrm{kg}$, respectively. She became fully conscious. Laparotomy was performed to correct a volvulus of the sigmoid colon, and several litres of proteinaceous fluid were removed from the bowel.

\section{CASE 2}

A 60 year old normotensive woman (blood pressure 140/90 $\mathrm{mm} \mathrm{Hg}$ ) presented with a carcinoma of the transverse colon. Her plasma protein and albumin concentrations were 60 and $35 \mathrm{~g} / \mathrm{l}$, respectively, and plasma sodium concentration $138 \mathrm{mmol} / \mathrm{l}$; plasma concentrations of other electrolytes and urea were normal. The segment of carcinomatous colon was resected, and no evidence of metastasis was found. During the postoperative period she was not given any parenteral nutrition. She was depressed and anorectic and refused oral feeds. She became progressively drowsy and had two epileptic seizures. No localising signs were found in the postictal phase, although she had bilateral extensor plantar responses. Electroencephalography showed a diffuse bilateral abnormality. Blood pressure was $125 / 80 \mathrm{~mm} \mathrm{Hg}$. Relevant plasma concentrations were sodium $104 \mathrm{mmol} / \mathrm{l}$, potassium $3 \mathrm{mmol} / \mathrm{l}$, chloride $85 \mathrm{mmol} / \mathrm{l}$, bicarbonate $19 \mathrm{mmol} / \mathrm{l}$, urea $2 \mathrm{mmol} / 1(12 \mathrm{mg} / 100 \mathrm{ml})$, uric acid $0.3 \mathrm{mmol} / 1(5 \mathrm{mg} / 100 \mathrm{ml})$, total protein $45 \mathrm{~g} / \mathrm{l}$, albumin $20 \mathrm{~g} / \mathrm{l}$, glucose $3.5 \mathrm{mmol} / 1(63 \mathrm{mg} / 100 \mathrm{ml})$. Serum osmolality was $215 \mathrm{mmol} / \mathrm{kg}$ and urinary osmolality $580 \mathrm{mmol} / \mathrm{kg}$. Her fluid intake was restricted to $500 \mathrm{ml}$ daily. Plasma sodium concentration increased marginally to $107 \mathrm{mmol} / 1$ and osmolality to $225 \mathrm{mmol} / \mathrm{kg}$ as a result of this restriction.

Two litres of plasma and a unit of blood were infused; this resulted in an increase in plasma albumin concentration to $33 \mathrm{~g} / \mathrm{l}$, plasma sodium concentration to $128 \mathrm{mmol} / \mathrm{l}$, and serum osmolality to $275 \mathrm{mmol} / \mathrm{kg}$, while urinary osmolality fell to $350 \mathrm{mmol} / \mathrm{kg}$. Plasma concentrations of other electrolytes and blood urea and uric acid concentrations increased to within the normal range. She became fully conscious, and regular high protein oral feeds were started. Subsequently her plasma albumin concentration was above $35 \mathrm{~g} / \mathrm{l}$, plasma sodium concentration above $134 \mathrm{mmol} / \mathrm{l}$, and serum osmolality above $280 \mathrm{mmol} / \mathrm{kg}$. During follow up of one year in the metabolic clinic no further electrolyte abnormalities were observed.

\section{CASE 3}

A 78 year old woman was admitted in a state of confusion. She had a long history of cardiac failure and was taking frusemide $80 \mathrm{mg}$ daily and spironolactone $100 \mathrm{mg}$ daily. On examination she was dehydrated and her blood pressure was $90 / 60 \mathrm{~mm} \mathrm{Hg}$. No focal neurological signs were found. Her plasma urea concentration was $24.4 \mathrm{mmol} / 1(147 \mathrm{mg} / 100 \mathrm{ml})$, sodium $122 \mathrm{mmol} / 1$, potassium $4.4 \mathrm{mmol} / \mathrm{l}$, albumin $31 \mathrm{~g} / \mathrm{l}$, and random serum cortisol $900 \mathrm{nmol} / \mathrm{l}(32.6 \mu \mathrm{g} / 100 \mathrm{ml})$. Computed tomography showed multiple cerebral infarctions.

Diuretics were stopped, and she was rehydrated with intravenous saline and potassium chloride. Ten days after admission she was still confused; her blood pressure was $110 / 70 \mathrm{~mm} \mathrm{Hg}$, and plasma concentrations were urea $10 \mathrm{mmol} / 1(60 \mathrm{mg} / 100 \mathrm{ml})$, sodium $116 \mathrm{mmol} / 1$, potassium $4.7 \mathrm{mmol} / \mathrm{l}$, and albumin $30 \mathrm{~g} / 1$. Her plasma osmolality was $259 \mathrm{mmol} / \mathrm{kg}$ and simultaneous urine osmolality $580 \mathrm{mmol} / \mathrm{kg}$. The central venous pressure was $-2 \mathrm{~cm}$ of water.

She was given an infusion of a $20 \%$ human albumin solution (Albumin Kabi, Kabivitrum Limited, United Kingdom, which contains $120 \mathrm{mmol}$ sodium/l) $200 \mathrm{ml}$ daily for three days. Her central venous pressure rose to $8 \mathrm{~cm}$ and her plasma sodium concentration to 125,127 , and $128 \mathrm{mmol} / \mathrm{l}$, respectively, on successive days. Plasma albumin concentration rose to $34 \mathrm{~g} / \mathrm{l}$, plasma osmolality rose to $276 \mathrm{mmol} / \mathrm{l}$, and urine osmolality fell to $430 \mathrm{mmol} / \mathrm{kg}$.

\section{Association of hyponatraemia and hypoalbuminaemia in routine laboratory tests}

To ascertain whether there was an association between low sodium and albumin concentrations we collected results from a random series of 3852 patients tested at this hospital. Of these patients, 111 had plasma sodium concentrations $\leqslant 130 \mathrm{mmol} / \mathrm{l}$. Sixty one of these $111 \mathrm{had}$ either abnormal liver or abnormal renal function. As patients with liver or renal disease often have hyponatraemia due to a variety of causes - that is, not necessarily due to concomitant hypoalbuminaemia - we excluded these 61 patients from further consideration. Of the remaining 50 patients with a plasma sodium concentration $\leqslant 130 \mathrm{mmol} / \mathrm{l}, 41$ had their plasma albumin concentrations measured; $17(42 \%)$ of these had albumin concentrations below $32 \mathrm{~g} / \mathrm{l}$. In contrast, in a sample of 232 consecutive patients with plasma sodium concentrations above $130 \mathrm{mmol} / \mathrm{l}$ who also had normal renal and liver function low albumin concentrations (below $32 \mathrm{~g} / \mathrm{l}$ ) were found in 11 of the 207 patients $(5 \%)$ whose concentrations were measured. This difference in the association of hypoalbuminaemia between patients with normal and low sodium concentrations was highly significant $(\mathrm{p}<0.01)$.

\section{Discussion}

The cases reported here, and the additional data on other patients with hypoalbuminaemia, show that hypoalbuminaemia and hyponatraemia are associated; correction of the hypoalbuminaemia in the cases reported resulted in normal plasma sodium concentrations and plasma osmolality and a fall in urinary osmolality. The concomitant fall in urinary osmolality with an increase in plasma osmolality indicated that excessive secretion of antidiuretic hormone in these patients had stopped after the correction of hypoalbuminaemia (table). Furthermore, in at least two patients concentrated albumin (20\%) was the only substance infused; this preparation contains only $120-160 \mathrm{mmol}$ sodium/l, and an infusion of $100 \mathrm{ml}$ would provide $20 \mathrm{~g}$ albumin while adding only 13 $16 \mathrm{mmol}$ sodium to a plasma volume of 2-3 litres in patients with hypovolaemia. The presumed inhibition of oversecretion of antidiuretic hormone also shows that the increase in sodium was not due merely to an infusion of sodium contained in plasma or albumin preparations. Furthermore, infusion of hypertonic saline in other patients with inappropriate secretion of antidiuretic hormone results in an increase in the excretion of sodium in the urine, not a decrease.

The restoration of a normal plasma albumin concentration tends to return plasma volume to a normal value. This would result in the switching off of the stimulus that triggers the hypersecretion of antidiuretic hormone. The association of hyponatraemia and hypoalbuminaemia is therefore probably causal. We should mention here that the hypersecretion of antidiuretic hormone in response to hypoalbuminaemia and hypovolaemia is not inappropriate. It is known that a low circulating volume is an extremely potent stimulus for the secretion of antidiuretic hormone, ${ }^{3-7}$ so that hypersecretion of antidiuretic hormone in this setting persists despite the low plasma osmolality. In this context it would have been interesting to measure plasma volume in each of these patients before and after infusions of albumin and plasma, but because this study was retrospective and aimed to define a new cause of hyponatraemia plasma volume measurements were unfortunately not done. In a prospective study we are attempting to define a relation between plasma albumin concentration, volume, osmolality, and concentrations of antidiuretic hormone as well as studying the effect of albumin infusions on these variables in patients with hypoalbuminaemia.

Whereas hypovolaemia is a known stimulus for the secretion of

(1)

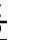
\& 
antidiuretic hormone, hypoalbuminaemia is not recognised as an important and reversible cause of clinically important hyponatraemia. Recent authoritative reviews on this subject do not mention a low plasma albumin concentration and its treatment either as a cause or as a mode of management of excessive secretion of antidiuretic hormone or hyponatraemia, or both..$^{3.8}$ This is surprising as plasma albumin concentration and the oncotic pressure generated by it are major factors determining plasma volume. The association of mild hyponatraemia (plasma sodium concentrations of $130-135 \mathrm{mmol} / \mathrm{l}$ ) with hypoalbuminaemia has recently been shown in patients with the nephrotic syndrome.' These patients had higher concentrations of antidiuretic hormone in their plasma and lower plasma sodium concentrations and relatively higher urinary osmolality than did controls. Infusion of albumin in these patients resulted in normal plasma albumin, sodium, and antidiuretic hormone concentrations and normal plasma volumes.

The only other linking of hyponatraemia with hypoalbuminaemia that we have found was based on a hypothesis, not clinical evidence. ${ }^{1}$ The hypothesis suggested that a fall in plasma albumin concentrations would result in a fall in total anions in plasma; this would be compensated for by a fall in cations, including sodium. The hypothesis does not explain how this compensatory fall occurs. In addition, the total anionic capacity of albumin in plasma is roughly $5-7 \mathrm{mmol} / \mathrm{l}$. Even if albumin concentrations fell by $50 \%$ it would not be possible to account for a reduction in sodium concentration of more than $5 \mathrm{mmol} / \mathrm{l}$. Furthermore, this hypothesis does not explain the excessive secretion of antidiuretic hormone.

We also found a report describing a patient with chronic asymptomatic hyponatraemia due to inappropriate secretion of antidiuretic hormone, in whom no neoplasm or other cause could be found despite detailed investigation. Expansion of circulating volume in this patient rectified temporarily the plasma and urinary abnormalities caused by inappropriate secretion of antidiuretic hormone. ${ }^{10}$ Unfortunately, the authors did not provide data about the plasma concentration of proteins or albumin or mention that plasma protein concentrations may be important in the pathogenesis of inappropriate secretion of antidiuretic hormone.

The association of hyponatraemia with hypoalbuminaemia in randomly collected results from the clinical biochemistry laboratory must be evaluated critically as it does not necessarily establish a causal relation, as is demonstrated by the dramatic case histories reported above. Severe illness with malnutrition may result in both a failure of membrane sodium and potassium adenosine triphosphatase activity and hypoalbuminaemia. Thus in the group of patients with concomitantly low sodium and albumin concentrations some are likely to have the so called "sick cell" syndrome." This does not, however, rule out the possibility that in some patients with the sick cell syndrome hypoalbuminaemia and hypovolaemia may contribute to their hyponatraemia.

Two of our patients presented with cancer of the bowel, for which they had resections. Malnutrition before and after the operation resulted in hypoalbuminaemia; this was not directly caused by the tumour, which in both cases was resected totally. Hyponatraemia ensued and was corrected by infusions of plasma and albumin. These facts emphasise the importance of good nutritional care in patients undergoing surgery and the relevance of hypoalbuminaemia in the pathogenesis of hyponatraemia in such patients.

In conclusion, hypovolaemia due to hypoalbuminaemia may result in hypersecretion of antidiuretic hormone and thus cause hyponatraemia and urinary hyperosmolality. Such a clinical and biochemical condition may be confused with inappropriate secretion of antidiuretic hormone and may result in inappropriate treatment. The correct approach is the replenishment of the plasma volume through infusions of plasma and albumin to correct hyponatraemia.

\section{References}

1 Flear CT, Gill GV. Hyponatraemia: mechanisms and management. Lancet 1981;ii:26-31.

2 Buckley BM, Broughton PMG, Russell LJ, Carter TJN. New ways with old ions. Ann Clin Biochem 1984;21:75-7.

3 Zerba $R$, Stropes $L$, Robertson G. Vasopressin function in the syndrome of inappropriate antidiuresis. Annu Rev Med 1980;31:315-28.

Baylis PH. Posterior pituitary function. J Clin Endocrinol Metab 1983;12:747-70.

5 Goetz KL, Bond GC, Bloxham DD. Effect of moderate haemorrhage in humans on plasma ADH and renin. Proc Soc Exp Biol Med 1974;145:227-80.

6 Robertson GL, Atahk S. The interaction of blood osmolality and blood volume in regulating plasma vasopressin in man. $\mathcal{A}$ Clin Endocrinol Metab 1976;42:613-20.

7 Schrier RW, Berl T, Anderson RJ. Osmotic and non-osmotic control of vasopressin release. Am $\mathcal{F}$ Physiol 1979;236:321-32.

8 Schrier RW. Treatment of hyponatraemia. N Engl f Med 1985;312:1121-3.

9 Usberti M, Federico S, Macariello S, et al. Role of plasma vasopressin in the impairment of water excretion in nephrotic syndrome. Kidney Int 1984;25:422-9.

10 Bear RA, Drummond J, Halperin ML. Inappropriate secretion of ADH: correction of hyponatraemia by expansion of intravascular fluid volume. Can Med Assoc f 1982;126:275-6.

(Accepted 10 fuly 1985)
A young woman is discovered to be HTLV III positive and asks for advice about how this would affect her babies if she became pregnant. What are the chances that they would become infected and what are the chances that they would develop the acquired immune deficiency syndrome and die within a few years of birth? (I realise that the long term outlook will not be known for many years.)

Of all the unanswered questions concerning HTLV III/LAV infection, this is among the most important and the most difficult. There are insufficient data at present to assess accurately the chances of intrauterine infection and development of the acquired immune deficiency syndrome. Virtually all reported cases of transplacental infection and AIDS in infancy have occurred in mothers who had known risk factors such as intravenous drug abuse or sexual contact with infected men. With the advent of blood donor screening there is the increased likelihood of discovering antibody in subjects with no apparent risk factors. Limited data from several prospective studies suggest that the vertical transmission rate of the virus may be over $50 \%$ and in those babies infected at least $50 \%$ may develop AIDS in the short term. ${ }^{1}$ It must be emphasised, however, that these figures may be misleading as maternal infection was determined by identifying mothers of infants with AIDS from previous pregnancies.

Current recommendations in the United States distinguish between "high" and "low" risk women. ${ }^{2}$ High risk women (HTLV III/LAV antibody positive with known risk of exposure to the virus) are advised that any offspring are at increased risk of acquiring AIDS. Low risk women (HTLV III/LAV antibody positive with no known risk of exposure) are advised that there is insufficient evidence to warrant advising blanket postponement of pregnancy. An important additional factor to consider, however, is the possibility that pregnancy may precipitate the development of AIDS in the previously symptom free HTLV III/LAV infected woman.
Again, data are limited but studies in high risk women suggest that this is likely. Informed and sensitive counselling of seropositive women of childbearing age is essential.—D J JEFFRIES, head of virology, London.

1 Pinching AJ, Jeffries DJ. AIDS and HTLV III/LAV infection: consequences for obstetrics and perinatal medicine. Brf Obstet Gynaecol (in press).

Association of State and Territorial Health Officials Foundation. Guide to public health practice: HTLV III screening in the community. ASTHO, 1985. (Publication No 77. Copies may be ATLV III screm G J Che Kensington, Maryland 20895, USA.)

WORDS GUANO is the accumulated excreta of sea birds and, by extension, of any birds and of bats and seals. Massive deposits, over two hundred feet thick on some islands off South America, are exported as fertiliser, as it is a useful source of nitrogen, phosphate, and potassium. Guano is a Spanish word taken from huano, dung, in the Quechua language. At the time of the Spanish conquest of the Incas, Quechuan was spoken along the east coast of South America from Colombia, Ecuador, and Peru as far as mid-Chile, and it is still spoken by several million people. In $1850 \mathrm{a}$ compound was extracted from guano bearing some resemblance to the xanthines. Accordingly, its discoverer ${ }^{1}$ named it GUANINE. A century later Watson and Crick discovered that guanine is one of the four basic substances that are integral in the molecular structure of DNA. GUANIDINE, originally prepared from guanine, has several derivatives of industrial use. It is also a molecular component of creatine and arginine, and of the antimalarial drug PROGUANIL, the hypotensive drug GUANETHIDINE, and the intestinal antimicrobial SULPHAGUANIDINE. - B J FREEDMAN.

1 Fownes G. A manual of elementary chemistry. 3rd ed. London: John Churchill, 1850. 